\title{
Critical Aspects of the Inclusive Environmental for the Well-being of Building Occupant - A Review
}

\author{
Kamaruzzaman S.N ${ }^{1 a}$, Noor Ashiqin ${ }^{2}$, Ahmad Zawawi E.M ${ }^{3}$, Mike Riley $^{4}$ \\ 1,2Department of Building Surveying, Faculty of Built Environment, University Malaya, \\ Kuala Lumpur \\ ${ }^{3}$ Faculty of Architecture, Planning \& Surveying, University Technology Mara, \\ Shah Alam, Selangor \\ ${ }^{4}$ Liverpool John Moores University
}

\begin{abstract}
In the property, design and construction industry the main focus of sustainability has been seen to affect the environmental such as climate change and resource depletion. Even though building may meet the recommended standards overall, but yet occupants still complain about several aspects. Indoor environmental quality consequently affects health, productivity and well-being of building occupants as most of them spend their time in indoor space. Therefore they are at risks for air pollutant occurs in the indoor air of dwellings such as volatile organic compounds, paints, ventilation, and others environmental pollutant. This paper reviews the potential health consequences in changes of climates change whereby developed countries contributed in energy consumption and greenhouse gas emissions. From the review search by 57 publications, the literature discussing about how thermal, acoustic and visual comfort as well as indoor air quality affects the satisfaction in indoor environmental quality and impacts to the human health. However, from the undertaken review most of the studies only highlighted on one aspects of indoor environmental quality. A number of critical aspects which give direct impacts to occupants have been identified. Subsequently, among all aspects such as lighting, ventilation, acoustics or humidity and thermal but thermal comfort perceived to influence overall satisfaction of occupants in the building. Thus, from the study revealed the critical aspects of indoor environment and contribute to the improvement for well-being and productivity of building occupants.
\end{abstract}

Keywords: Building performance, Environmental health and safety, Green building, Indoor environmental quality, Occupant

\subsection{Introduction}

Over decades, climate change has become a major issue globally due to the increasing of global temperatures and extreme weather conditions [1]. Consequently, this climate change may affect to dwellings that are more likely to spend their time indoors $[2,3]$. The review of the linkages of Climate Change with Indoor Environmental Quality (IEQ) whereby have been reported by a committee of the Institute of Medicine (IOM) can be referred at Fig 1. In addition, study conducted in UK shows the time consume by participants spending an average of $95.6 \%$ of their time indoors, with $66 \%$ of their time spent in their homes. It is supported by several studies pointed out that people in developed countries are more likely to spend $90 \%$ of their time indoors $[4,5,6]$. Thus, the risks to health posed by the exposure to indoor pollution are greater rather than outdoor air pollution. Subsequently, various aspects have been documented such as exposure to light, indoor air quality, temperature, odors, noise and ergonomics whereby those affect occupant performance and well-being [7].

Moreover, in high income country the building industry being a main contributor in energy consumption and greenhouse gas (GHG) emissions. For example the residential buildings in UK produce around $25 \%$ of total GHG end - user emissions in 2012 (DECC 2014).

\footnotetext{
${ }^{a}$ Corresponding author: syahrulnizam@um.edu.my
} 
Fig.1. Examples of how Climate Change may affect indoor environments and health [3].

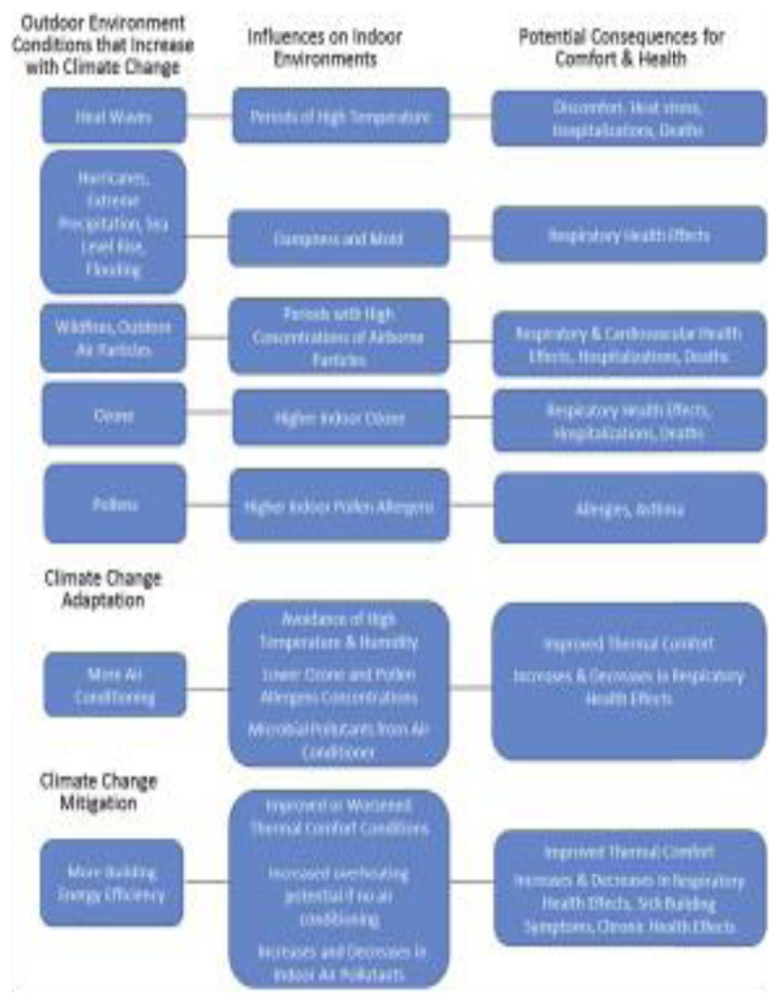

Building should provide shelter and enhance wellbeing to occupant however it also associated with a range of health hazards like indoor air pollution, extreme temperatures, pests and infestations, noise, airborne infectious diseases, water or mould contamination, domestic injuries and mental health effects [8].

In addition, from the studies by [9] indicates that costs of poor indoor environment for the employer, building owner and society as a whole are often considerable greater than the cost of the energy used in the same building. Nonetheless, the good indoor environmental quality can improve overall work, learning performance and reduce absenteeism. There are numbers of paper have recently reviewed, [10] point out on the effects of single environmental conditions on human such as examiné which conditions lead to satisfaction with the visual and acoustic environment .Besides that, studies by [11] concern about which factors are not significant to the indoor environment and again they highlighted more on satisfaction with a single environmental condition such as visual environment or thermal environment [12]. Subsequently, from the research studies tended to consider environmental comfort such as temperature, velocity, radiant temperature and humidity but none have considered lighting, noise and smell. The purposes on that, this paper reveal critical aspects of the inclusive environmental that influence the well-being building occupants.

\subsection{Overview of Indoor Environmental Quality in Buildings}

The issues pertaining to the health, well-being and comfort to the building occupants with a satisfactory indoor environment needs to be highlighted especially in developed countries. In UK, by law it is a requirement for the building owner to have an energy performance certificate [13].Subsequently, we can see the trends toward providing a developing system for better building assessment scale in local, global and indoor environmental scale [14]. However, studies regarding achieving an optimal satisfaction indoor environment for all building occupant facilities can assumed as scarce [15]. Thus, it is crucial to educate people to have an awareness and knowledge for better understanding of indoor environment influence. In the point of view [16] he suggested on green building design in order to provide satisfaction in health, comfort and well-being performance of building occupants. Therefore, standards and guideline are based with IEQ parameter whereby it is combined with effects on occupants satisfaction and efficiency [17]

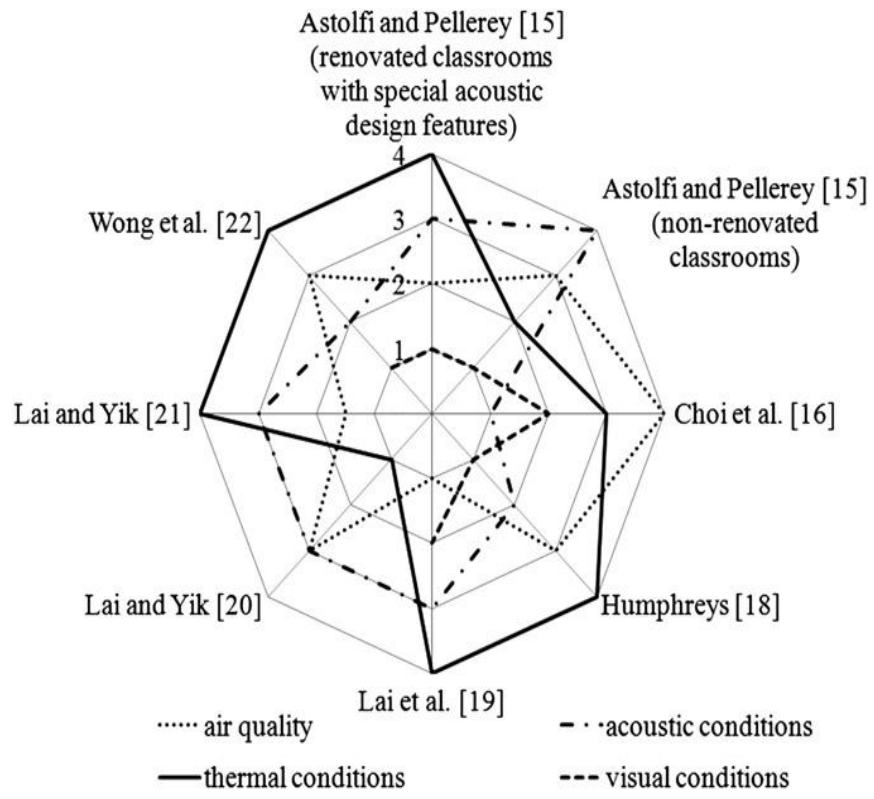

Fig. 2. Ranking of the importance of different environmental conditions for overall satisfaction with IEQ

However, in terms of IEQ [18] suggested, the standards and guidelines should be changed and fashioned in order to enhance occupants optimal comfort and efficiency. Numbers of studies have been conducted according to indoor environmental quality of buildings in occupants. Factors that have the relationship between IEQ was studied by $[19 ; 20 ; 21]$ while the integration of the parameters of IEQ into mathematical models studies conducted by $[22 ; 23 ; 24 ; 25]$.

${ }^{a}$ Corresponding author: syahrulnizam@um.edu.my 
Other than that, according to [26] suggested that, acceptability of overall indoor environment should depends on average acceptance of all the indoor environmental parameters at certain acceptability level. Besides that, [27] indicate the physical environment and people response must take into consideration while designing an environment for people. Poor indoor environmental quality may result into sick building syndrome (SBS) as stated by [28].
Moreover, improvement to indoor environmental quality in building occupants achieved when all factors of indoor environmental quality parameters are taken into account. These indoor environmental factors include thermal comfort, acoustic comfort, noise and ergonomics. Figs 2 indicate the ranking of overall satisfaction among building occupant with IEQ from previous studies. The result shown the highest rankings are most important.

${ }^{\text {a }}$ Corresponding author: syahrulnizam@um.edu.my 
Table 1: Components of critical aspects from previous study

\begin{tabular}{|c|c|c|}
\hline Aspects & Author & Finding \\
\hline $\begin{array}{l}\text { 1.Visual } \\
\text { comfort }\end{array}$ & [29] & $\begin{array}{l}\text { Author agrees with all factors of visual comfort such as the amount of light, the uniformity, the } \\
\text { quality and rendering quality. } \\
\text {-Define in European standard EN12665 a subjective condition of visual well-being induced by the } \\
\text { visual environment (EN12665, 2011) } \\
\text {-Depends on the physiology of the human eye, physical quantities, describe the amount of light and } \\
\text { distribution in space, spectral emission of the light. }\end{array}$ \\
\hline $\begin{array}{l}\text { 2. Indoor } \\
\text { Air Quality }\end{array}$ & {$[30]$} & $\begin{array}{l}\text {-Indicates that guidelines and standards set for adherence are dependent on adverses health effects } \\
\text { which could potentially occur from exposure. } \\
\text { - All examined pollutants are experienced similarly by the countries on each continent with } \\
\text { Relatively similar guidelines. } \\
\text { - Other factors such as temperature, humidity, and air movement, which are correlated, } \\
\text { interchangeably affect each other and chemical pollutants. }\end{array}$ \\
\hline $\begin{array}{l}\text { 3.Indoor } \\
\text { Environmen } \\
\text { tal Quality } \\
\text { (IEQ) }\end{array}$ & {$[31]$} & $\begin{array}{l}\text {-No attempt has been made towards validating thermal comfort, acoustic comfort, visual comfort } \\
\text { and indoor air quality as parameters of measures of IEQ in hospital buildings. } \\
\text {-There is therefore, a need for the validation of the IEQ parameters of measurement as a basis for } \\
\text { the development of an integrated IEQ performance evaluation model. }\end{array}$ \\
\hline $\begin{array}{l}\text { 4.Indoor } \\
\text { Environmen } \\
\text { tal Quality }\end{array}$ & [32] & $\begin{array}{l}\text {-The environmental factors are: thermal comfort, indoor air quality, acoustic comfort and visual } \\
\text { comfort }\end{array}$ \\
\hline $\begin{array}{l}\text { 5.Indoor } \\
\text { environmen } \\
\text { tal Quality }\end{array}$ & [33] & $\begin{array}{l}\text {-The paper investigates the interactions between global satisfaction for workers in hypermarkets } \\
\text { and the different attributes that contribute to it. } \\
\text { - Factor analysis pointed out the existence of two main groups of dissatisfied. } \\
\text { - The first one gave greater relevance to visual and acoustic aspects while being neutral towards } \\
\text { thermal aspects. } \\
\text {-Conversely, the second group was more influenced by lack of thermal comfort and presence of } \\
\text { local discomfort, while showing indifference towards visual and acoustic aspects. } \\
\text {-Application of Kano's model showed that thermal local discomfort and IAQ were considered } \\
\text { "basic" aspects (i.e. they have negative effect on global satisfaction when they underperform), } \\
\text { - While acoustic comfort was considered a "bonus" aspect, capable to improve overall rating when } \\
\text { it performed well. } \\
\text {-Visual and thermal comfort had a mostly linear influence on global satisfaction but also proved to } \\
\text { have the highest impact. }\end{array}$ \\
\hline $\begin{array}{l}\text { 6.Indoor } \\
\text { Air Quality }\end{array}$ & [34] & $\begin{array}{l}\text { - Author explored a range of health risks in the domestic indoor environment related to climate } \\
\text { change, as well as the potential health benefits and unintended harmful effects of climate change } \\
\text { mitigation and adaptation policies in the UK housing sector. } \\
\text { - Effect includes indoor temperatures, indoor air quality, indoor allergens and infections, and } \\
\text { flood damage and water contamination. } \\
\text { - Certain changes to the indoor environment can affect indoor air quality or promote the growth } \\
\text { and propagation of pathogenic organisms. Measures aimed at reducing greenhouse gas emissions } \\
\text { have the potential for ancillary public health benefits including reductions in health burdens related } \\
\text { heat and cold, indoor exposure to air pollution derived from outdoor sources, and mould growth. } \\
\text { - Increasing airtightness of dwellings in pursuit of energy efficiency could also have negative } \\
\text { effects by increasing concentrations of pollutants (such as PM2.5, CO and radon) derived from } \\
\text { indoor or ground sources, and biological contamination. } \\
\text {-High risk of these adverse health effects include the elderly (especially those living on their own), } \\
\text { individuals with pre-existing illnesses, people living in overcrowded accommodation, and the } \\
\text { socioeconomically deprived..Ventilation is a key aspect that affects indoor air quality (chemical } \\
\text { and microbial).Moisture-related allergens (mould and dust mites) and thermal comfort in dwellings }\end{array}$ \\
\hline $\begin{array}{l}\text { 7. Thermal } \\
\text { Visual } \\
\text { Acoustic }\end{array}$ & [35] & $\begin{array}{l}\text {-Suggest that when developing systems for controlling the indoor environment, the type of } \\
\text { building and outdoor climate, including season, should be taken into account. } \\
\text { - Providing occupants with the possibility to control the indoor environment improves thermal and } \\
\text { visual comfort as well as satisfaction with the air quality. Thermal comfort is ranked by building } \\
\text { occupants to be of greater importance compared with visual and acoustic comfort and good air } \\
\text { quality. }\end{array}$ \\
\hline
\end{tabular}

${ }^{a}$ Corresponding author: syahrulnizam@um.edu.my 


\begin{tabular}{|c|c|c|}
\hline Aspects & Author & Finding \\
\hline $\begin{array}{l}8 . \\
\text { Indoor air } \\
\text { pollutants: }\end{array}$ & {$[36]$} & $\begin{array}{l}\text { - The measured parameters were temperature, relative humidity, CO2, and the indoor air } \\
\text { pollutants: fourteen individual volatile organic compounds (VOC), four aldehydes and } \\
\text { particulate matter PM10 and PM2.5 } \\
\text { - Concentration of formaldehyde was approximately } 30 \% \text { higher in dwellings built after } 1990 \\
\text { compared with older ones; it was higher in dwellings with mechanical ventilation and in } \\
\text { concrete buildings. }\end{array}$ \\
\hline $\begin{array}{l}\text { 9.Indoor } \\
\text { Environmental } \\
\text { Quality }\end{array}$ & [37] & $\begin{array}{l}\text {-The most common weekly symptoms in the spring semester were fatigue }(7.7 \%) \text {, stuffy nose } \\
(7.3 \%) \text {, and headache }(5.5 \%) \text {. } \\
\text {-The most frequently reported IEQ factors causing daily inconvenience in classrooms were } \\
\text { noise }(11.0 \%) \text { and stuffy air/poor indoor air quality (IAQ) }(7.0 \%) \text {, which were also found most } \\
\text { frequently above } 95 \% \mathrm{CI} \text { on the group level (calculated for } \mathrm{N}=15) \text {, together with self-reported } \\
\text { high indoor temperature and dust or dirtiness. }\end{array}$ \\
\hline $\begin{array}{l}\text { 10.Indoor } \\
\text { Environmental } \\
\text { Quality }\end{array}$ & {$[8]$} & $\begin{array}{l}\text {-It was found that day-lighting, electric lighting and glare were five out of the seven factors } \\
\text { found most dissatisfied aspects of the buildings. } \\
\text { - Electric lighting was used for almost all the time the occupants were in the buildings. } \\
\text { - This study provides significant impact on creating change in terms of improving building } \\
\text { environment in two ways. } \\
\text {-Providing lessons and feedback for owners or those involved in the environment improvement } \\
\text { works. This could lead to enhanced quality of indoor environment by addressing the changing } \\
\text { needs of occupants }\end{array}$ \\
\hline $\begin{array}{l}\text { 11. Ventilation } \\
\text { in } \\
\text { Indoor air } \\
\text { quality } \\
\text { Standard }\end{array}$ & [38] & $\begin{array}{l}\text {-This paper reviews and discusses some of the issues that have been addressed in the } \\
\text { development of ventilation standards in recent years, using the development of ASHRAE } \\
\text { Standard } 62 \text { as context, including: the scientific bases for ventilation requirements, perceived } \\
\text { indoor air quality, contaminant sources from occupants and the building, } \\
\text {-outdoor air quality, airborne contaminant limits, indoor carbon dioxide concentrations, } \\
\text { environmental tobacco smoke, and performance-based design }\end{array}$ \\
\hline 12. Noise & [39] & $\begin{array}{l}\text { - Four studies reported that wind turbine noise significantly interfered with QOL. } \\
\text {-visual perception of wind turbine generators was associated with greater frequency of reported } \\
\text { negative health effects.. } \\
\text { - Evidence that exposure to wind turbine noise is associated with increased odds of annoyance } \\
\text { and sleep problems. Individual attitudes could influence the type of response to noise from wind } \\
\text { turbines. } \\
\text {-to explore the association between wind turbine noise, annoyance, sleep and quality of life. }\end{array}$ \\
\hline $\begin{array}{l}\text { 13. Indoor } \\
\text { temperature, } \\
\text { relative } \\
\text { humidity, and } \\
\text { carbon dioxide } \\
\text { concentration }\end{array}$ & [40] & $\begin{array}{l}\text {-In conclusion, there were large differences between occupant self-reported satisfaction and } \\
\text { thermal comfort by tenure status, but differences in measured parameters were relatively small. } \\
\text {-The results indicate that occupant characteristics are likely to explain a majority of differences } \\
\text { by tenure status, which should be taken into account when assessing the overall relationships } \\
\text { between housing and health. }\end{array}$ \\
\hline 14.Noise & [41] & $\begin{array}{l}\text {-Determined the risk of noise for the incidence of myocardial infarction. } \\
\text {-Chronic noise burden is associated with the risk of myocardial infarction. The risk increase } \\
\text { appears more closely associated with sound levels than with subjective annoyance. Further } \\
\text { investigation of the gender-related risk of noise exposure may aid in improving prevention. }\end{array}$ \\
\hline $\begin{array}{l}\text { 15. Indoor air } \\
\text { quality (IAQ), } \\
\text { volatile organic } \\
\text { compounds } \\
\text { (VOCs) }\end{array}$ & [26] & $\begin{array}{l}\text {-As the occupancy period got longer, the VOCs originating from the construction phase were } \\
\text { increasingly replaced by new ones. } \\
\text {-Reference values based on means and on } 95 \text { percentiles are presented to facilitate interpretation } \\
\text { of the results of measurements done to ensure that proper construction practices have been } \\
\text { applied or to investigate IAQ problems }\end{array}$ \\
\hline
\end{tabular}

a Corresponding author: syahrulnizam@um.edu.my 


\subsection{Indoor Air Quality (IAQ)}

Generally, Indoor Air Quality (IAQ) term is used to describe the quality of air within a building. Average about $90 \%$ people spend their time inside their workplace or home therefore indoor air quality of building occupant is a basis determinant of healthy life, people well-being, comfort and productivity of the occupants. Prior to maintain a good IAQ it is important to identify the physical and chemical parameters which influence the comfort of building occupants whereby also proposed by the Industrial Code of Practice on Indoor Air Quality . The characteristics of good indoor air quality are adequate ventilation air, control of airborne contaminants and maintenance of acceptable temperature and relative humidity.

However, the failure on solving the problem immediately and efficiently regarding poor indoor air quality will affects the health, productivity and wellbeing of building occupants. According to the World Organization health, they reported that indoor air pollution contributes about $2.7 \%$ of the global burden disease. As supported by [42] by 2030 expected that if inappropriate indoor conditions may lead to more premature death than malaria or AIDS. Apart from that, indoor air quality gives direct impact on health if exposure to high concentrations of air pollutants indoor. In the studies conducted by [43], even short term exposure to high concentrations of carbon monoxide can cause acute effects such as intoxication and death. Besides that, [44] indicates the chronic health effects include radon related lung cancer and this caused by second hand tobacco smoke which lead to chronic obstructive pulmonary disease [45].

This supported by [46] whereby from their studies indicate that, second hand tobacco smoke can caused respiratory infections, cardiovascular disease and a range of allergic symptoms like atopic dermatitis, rhinitis, conjunctivitis and hay fever. Subsequently, there has a significant between indoor air quality and efficiency. In the studies by [47] point out, small changes in temperatures impact the quantity and quality of the produced work. Thus, improvement of the quality and quantity of outside air maximize natural ventilation and separate ventilation air from thermal conditioning indirectly improves pollution source control. International case study stated that, improvement in high performance ventilation contribute to reduce respiratory illness, increase in productivity as well as increasing in energy savings for natural ventilation and mixed mode conditioning [48].Subsequently, dwelling proximity to industrial and traffic pollution sources, increased indoor tobacco smoking, dampness, contaminated dusts consequently can affect the health problem due high concentration of pollutant [49] .In the Table 1 shows the effect of different carbon dioxide concentrations on human body. In living space the air composition are differ rather than outside. As refer from (Pettenkofer's number) the concentration of carbon dioxide in outside range between 300 and $400 \mathrm{ppm}$ while $900 \mathrm{ppm}$ in living space.
Table 2: The effects of $\mathrm{CO}_{2}$ concentration on human body [32].

\begin{tabular}{|c|c|l|}
\hline \multicolumn{2}{|c|}{ CO2 concentration } & \multirow{2}{*}{ Effects } \\
\hline [\%] & [ppm] & $\begin{array}{l}\text { Deep } \\
\text { breathing, } \\
\text { strong }\end{array}$ \\
\hline 3 & 30,000 & $\begin{array}{l}\text { Head } \\
\text { aches, } \\
\text { pulse, } \\
\text { dizziness, } \\
\text { Psychic } \\
\text { emotions }\end{array}$ \\
\hline 4 & 40,000 & $\begin{array}{l}\text { After } \\
0.5-1 \text { h } \\
\text { may cause } \\
\text { death }\end{array}$ \\
\hline 5 & 50,000 & $\begin{array}{l}\text { Sudden } \\
\text { death }\end{array}$ \\
\hline $8-10$ & $80,000-10,000$ & \\
\hline
\end{tabular}

\subsection{Relative Humidity}

Thermal comfort according [50] refer to the condition of mind which expresses satisfaction with thermal environment. However, this condition only met if no local discomfort exists such as building users not disturbed by draught, too low or high internal surface temperature or others. In addition, the standard (ISO $7730,1993)$ indicates it is difficult and possible to predict the mean thermal sensation and mean satisfaction with thermal condition in a group due to sharing the built environment with other occupants. The physical variables that associated with thermal comfort such as air temperature mean radiant temperature, relative air velocity and air humidity.

Moreover, relative humidity refers to the moisture content in the air which gives impact to the thermal comfort in the building. The low levels of humidity caused irritation due to decrease of mucus at the eyes and nose. However, high levels of humidity will ease the airborne pestilences transfer via dust particles into the respiratory pathway and results in bronchitis. In addition, [51] pointed out that increase pollutant emission from building material such as volatile organic compound are due to high humidity which result inferior indoor air quality. In China, they recommended the relative humidity indoor at range $40-80 \%$ in summer and $30-$ $60 \%$ in winter. Moreover, HKEPD, 1999 set their standards as $40-70 \%$ relative humidity needed for excellent and less than $70 \%$ are good indoor air quality. However, (DOSH, 2010) also set a standard as $40-70 \%$ while Singapore (Institute of Environmental Epidemiology, 1996) set their standards at $\leq 70 \%$ for office premises. Subsequently, according to (Air Duct Cleaners,2013) US have set standards regarding relative humidity whereby ASHRAE set standard relative

${ }^{\text {a }}$ Corresponding author: syahrulnizam@um.edu.my 
humidity values of $40 \% \quad 60 \%$ in summer while $30 \%$ to $60 \%$ in winter.

\subsection{Noise pollution and acoustic comfort.}

Noise is considered as environmental problem consequently health problem and annoyance for human being.

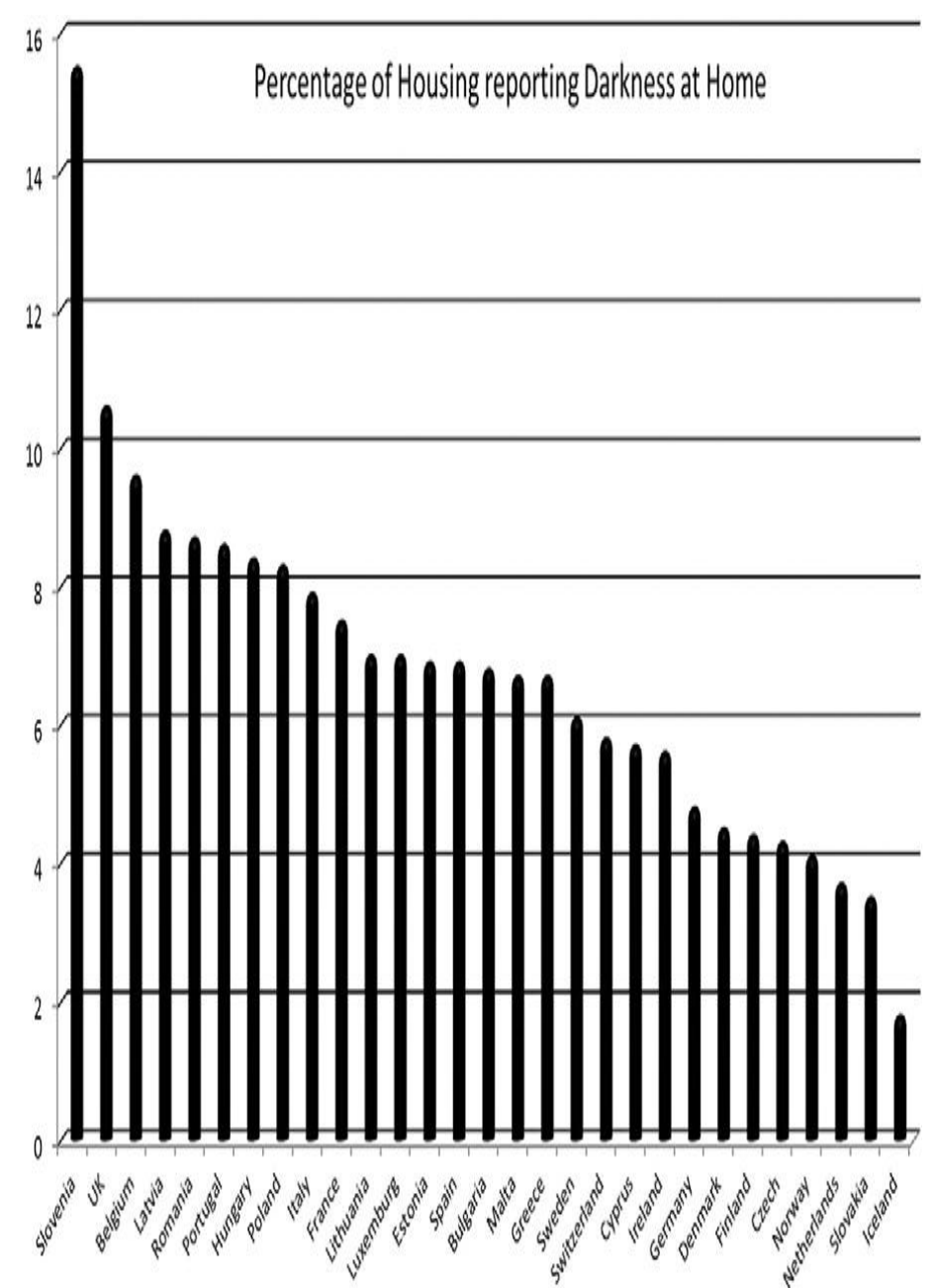

Fig. 3. Percentage of population suffering from noise pollution in the residential area among European countries (Rybkowska and Schneider, 2011).

In these factor can be differentiate psychosocial responses for example annoyance, sleep disturbance, disturbance of daily activities and performance while for physical responses such as hearing loss, hypertension and ischemic heart disease. Subsequently, according to [52] indicate that, exposure to noise problem can induce the changes in biochemical, physiologic, or psychosocial such as disturbance of sleep and daily activities, stress, and annoyance. In addition, these supported by [53], people living surrounded with noisy environment causing stress, present sleep disturbances and develop into habit of shouting. In addition, [54] conclude that people in urban household willing to spent about $4 €$ per year in order to achieve reduction of noise. However, from the study of noise against household income, indicate the low income occupants tend to exposed to noise than higher income [55].

In addition, the Fig 3 shows the percentage of households suffered with noise pollution. Subsequently, among all European countries, Romania, Cyprus, Malta, Germany and Netherlands a very high part of the population complaint to noise pollution which is $25-35 \%$. Moreover, in Italy, they carried out studies at the neighborhoods with traditional socio economic and the result also showing low quality neighborhoods are strongly health damaging low. Therefore from the result, [56] indicates that, noise pollution is a serious problem among overcrowded urban area.

\subsection{Discussion And Conclusion}

This study has reviewed about 57 publications which discussed the aspects of indoor environmental quality and affect the well-being of building occupants. From the previous studies, the main aspects which contribute most impact to occupants were identified such as indoor air quality, thermal comfort, visual and acoustic and noise. An overview of critical aspects influenced to the quality of the indoor environment whereby give direct impact to building occupants has been summarized in Table 1.

The studies on indoor environment in buildings in last decade only highlighted on individual parameter such as visual comfort $[31 ; 33 ; 34 ; 35 ; 28]$, acoustic comfort $[33 ; 35 ; 28]$, noise $[40 ; 42]$. It was found that from the studies conducted by $[38 ; 28]$ visual, thermal comfort and acoustic seems to influence to higher degree the overall satisfaction with indoor environmental quality compared to others aspects. Moreover [32;37] in IAQ aspects, they studies on temperature, carbon dioxide, indoor air pollutants as well as the relative humidity. From the studies [32] provides a standards and guidelines regarding IAQ issues. Besides that, temperature, humidity and air movement are correlated and affect each other. Moreover, the concentration of formaldehyde pointed out about $30 \%$ higher in dwellings built after 1990 [37]. In addition, the review from the case study conducted by $[35 ; 60]$ agreed that, among all aspects measured such as lighting, ventilation, acoustic or humidity and thermal comfort and yet thermal influences occupants overall satisfaction in building. Moreover, there is evidence in the literature undertaken by [61] indicate that increase level of pollutant such as volatile organic compounds leads to lower air quality.

Based on the literatures that have been reviewed, the conclusions that can be drawn from it are summarized as follows:

- Thermal comfort, acoustic comfort, visual comfort and indoor air quality has been as a crucial factors in indoor environmental quality.

- In addition, by create a comfortable thermal environment will lead to overall satisfaction with indoor environmental condition.

- Moreover, by provide people with self-control such as in term of ventilation in building will

\footnotetext{
a Corresponding author: syahrulnizam@um.edu.my
} 
improve thermal and visual comfort as well as indoor environment satisfaction.

- Most of the studies were focused only one aspects of indoor environmental quality or the other but no attempts on more than three aspects in the studies conducted by previous researchers.

\section{Acknowledgement}

The authors gratefully acknowledge the financial support of the UMRG RP015D-15SUS, Established at the University Malaya, sustainability science research cluster.

\section{References}

1. Nelson, A.J., Rakau, O. and Dörrenberg, P. (2010), Green Buildings - A Niche Becomes Mainstream, Deutsche Bank Research, Frankfurt am Main.

2. Crump, D., (2011). Climate Change- Health Impacts Due to Changes in the Indoor Environment;Research Needs. Cranfield University, Institute of Environment and Health.

3. Committee on the Assessment of Asthma and Indoor Air, Division of Health Promotion and Disease Prevention Staff, \& Institute of Medicine Staff. (1900). Clearing the air: asthma and indoor air exposures. National Academies Press..

4. Harrison, R.M., Thornton, C.A., Lawrence, R.G., Mark, D., Kinnersley, R.P., Ayres, J.G., 2002.Personal exposure monitoring of particulate matter, nitrogen dioxide, and carbon monoxide, including susceptible groups. Occup. Environ. Med. 59, 671-679.

5. Vardoulakis, S., 2009. Human exposure: indoor and outdoor. In: Air Quality in Urban Environments 28, 85-107.

6. Lai, H.K., Kendall, M., Ferrier, H., Lindup, I., Alm, S., Hänninen, O., Jantunen, M., Mathys, P.,Colvile, R., Ashmore, M.R., Cullinan, P., Nieuwenhuijsen, M.J., 2004. Personal exposures and microenvironment concentrations of PM2.5, VOC, NO2 and $\mathrm{CO}$ in Oxford, UK. Atmos. Environ. 38, 6399-6410.

7. Kamaruzzaman, S. N., Egbu, C. O., Zawawi, E. M. A., Ali, A. S., \& Che-Ani, A. I. (2011). The effect of indoor environmental quality on occupants' perception of performance: A case study of refurbished historic buildings in Malaysia. Energy and Buildings, 43(2), 407413.
8. WHO, 2011. Health Co-benefits of Climate Change Mitigation - Housing Sector. World Health Organization, Geneva.

9. Andersen, R. V., Toftum, J., Andersen, K. K., \& Olesen, B. W. (2009). Survey of occupant behaviour and control of indoor environment in Danish dwellings. Energy and Buildings, 41(1), 11-16.

10. Galasiu, A. D., \& Veitch, J. A. (2006). Occupant preferences and satisfaction with the luminous environment and control systems in daylit offices: a literature review. Energy and Buildings, 38(7), 728-742.

11. Veitch, J. A., \& Newsham, G. R. (2000). Exercised control, lighting choices, and energy use: An office simulation experiment. Journal of Environmental Psychology, 20(3), 219-237.

12. Nicol, J. F., Raja, I. A., Allaudin, A., \& Jamy, G. N. (1999). Climatic variations in comfortable temperatures: the Pakistan projects. Energy and Buildings, 30(3), 261-279.

13. Ncube, M., \& Riffat, S. (2012). Developing an indoor environment quality tool for assessment of mechanically ventilated office buildings in the UK-A preliminary study. Building and Environment, 53, 26-33.

14. Chiang, C., Lai, C., Chou, P., Li, Y., \& Tu, Y. (1999). The study on the comprehensive indicators of indoor environment assessment for occupants'health. In ASIA-PACIFICConference on the Built Environment 1993, Taipei, (pp. 17).

15. Paul, W.L., Taylor, P.A. (2008). A comparison of occupant comfort and satisfaction between a green building and a conventional building. Building and Environment (43), 1858-1870.

16. Salonen, H., Lahtinen, M., Lappalainen, S., Navala, N., Knibbs, L. D., Morawska, L.,et al. (2013). Design approaches for promoting beneficial indoor environmentsin healthcare facilities: A review. Intelligent Buildings International, 5(1), 26-50.

17. Smith, A., \&Pitt, M. (2011). Healthy workplaces: Plant scaping for indoor environmental quality Facilities, 29(3/4), 169187.

18. Huang, L., Zhu, Y., Ouyang, Q., \& Cao, B. (2012). A study on the effects of ther-mal, luminous, and acoustic environments on indoor environmental comfortin offices. Building and Environment, 49, 304-309.

19. Croitoru, C., Vartires, A., Bode, F., \& Dogeanu, A. (2013). Survey evaluation of theindoor

a Corresponding author: syahrulnizam@um.edu.my 
environment quality in a large Romanian hospital. INCAS Bulletin, 5(3),45-52.

20. Astolfi, A., \& Pellerey, F. (2008). Subjective and objective assessment of acousti-cal and overall environmental quality in secondary school classrooms. Journalof the Acoustical Society of America, 123, 163-173.

21. Humphreys, M. a. (2005). Quantifying occupant comfort: Are combined indices ofthe indoor environment practicable? Building Research \& Information, 33(4),317-325

22. Lai, A. C. K., Mui, K. W., Wong, L. T., \& Law, L. Y. (2009). An evaluation model forindoor environmental quality (IEQ) acceptance in residential buildings. Energyand Buildings, 41(9), 930-936.

23. Chiang, C., Lai, C., Chou, P., Li, Y., \& Tu, Y. (1999). The study on the comprehensive indicators of indoor environment assessment for occupants'health. In ASIA-PACIFICConference on the Built Environment 1993, Taipei, (pp. 17).

24. Heinzerling, D., Schiavon, S., Webster, T., \& Arens, E. (2013). Indoor environmentalquality assessment models: A literature review and a proposed weighting andclassification scheme. Building and Environment, 70, 210-222

25. Mui, K. W., \& Chan, W. T. (2005). A new indoor environmental quality equation forairconditioned buildings. Architectural Science Review, 48(1), 41-46.

26. Lai, A. C. K., Mui, K. W., Wong, L. T., \& Law, L. Y. (2009). An evaluation model forindoor environmental quality (IEQ) acceptance in residential buildings. Energyand Buildings, 41(9), 930-936

27. Frontczak, M., Andersen, R. V., \& Wargocki, P. (2012). Questionnaire survey on fac-tors influencing comfort with indoor environmental quality in Danish housing.Building and Environment, 50, 56-64.

28. De Giuli, V., Da Pos, O., \& De Carli, M. (2012). Indoor environmental quality and pupilperception in Italian primary schools. Building and Environment, 56, 335-345.

29. Abdul- Wahab, S.A., En, S.C.F.,Elkamel, A., Ahmadi, L., Yetilmezsoy, K. (2015). A review of standards and guidelines set by international bodies for the parameters of indoor air quality. Atmospheric Pollution Research (6) 751 -767.

30. Carlucci, S., Causone, F., Rosa, F.D., Pagliano, L.(2015). A review of indices for assessing visual comfort with a view to their use in optimization processes to support building integrated design. Renewable and Sustainable Energy Reviews (47)1016-1033

31. Abdul-Wahab, S. A., En, S. C. F., Elkamel, A., Ahmadi, L., \& Yetilmezsoy, K. (2015). A review of standards and guidelines set by international bodies for the parameters of indoor air quality. Atmospheric Pollution Research,6(5), 751-767.

32. Nimlyat, P.S., Kandar, M.Z. (2015) Appraisal of indoor environmental quality (IEQ) in healthcarefacilities: A literature review. Cities and Society ( 17) 61-68.

33. Sarbu, L.,Sebarchievici, C. (2013) . Review Aspects of indoor environmental quality assessment in buildings. Energy and Buildings (60)410-419.

34. Martellotta, F., Simone, A., Crociata, S.D, D'Alba, M.(2016).Global comfort and indoor environment quality attributes for workers of a hypermarket in Southern Italy. Building and Environment 95 . 355-364.

35. Vardoulakis, A., Dimitroulopoulou, C., Thornes, J. (2015).Review article Impact of climate change on the domestic indoor environment and associated health risks in the UK. Environment International 85.299-313.

36. A. Norhidayah, Lee Chia-Kuang, M.K. Azhar S. Nurulwahida. (2013). Indoor Air Quality and Sick Building Syndrome in Three Selected Building .Procedia Engineering ( 53 ) 93 - 98.

37. Langer, S., Ramalho, O., Derbez, M. (2016). Indoor environmental quality in French dwellings and building characteristics. Atmospheric Environment ( 128) 82-91.

38. Turunen, M., Toyinbo, O., Putus, T., Nevalainen, A. (2014) .Indoor environmental quality in school buildings, and the health andwellbeing of students. International Journal of Hygiene and Environmental Health ( 217 )733-739.

39. Persily, A. (2015) . Challenges in developing ventilation and indoor air quality standards:The story of ASHRAE Standard 62. Building and Environment .(91) 61-69.

40. Onakpoya, I. J., O'Sullivan, J., Thompson, M. J., \& Heneghan, C. J. (2015). The effect of wind turbine noise on sleep and quality of life: a systematic review and meta-analysis of observational studies. Environment international, 82, 1-9.

41. Pekkonen, M., Du a,L, Raatikainen, M. (2015). The influence of tenure status on housing satisfaction and indoorenvironmental quality in

${ }^{\text {a }}$ Corresponding author: syahrulnizam@um.edu.my 
Finnish apartment buildings.Building and Environment (89)134-140.

42. Willich, S.N., Wegscheider, K., M Stallmann, M.( 2006) . Noise burden and the risk of myocardial infarction Thomas Keil. European Heart Journal (27), 276-282.].

43. Lavelle, M., 2010. The Solvable Problem of Energy Poverty. National Geographic News.

44. Raub, J.A., Mathieu-Nolfb, M., Hampsonc, N.B., Thomd, S.R., 2000. Carbon monoxide poisoning - a public health perspective. Toxicology 145 (1), 1-14.

45. Darby, S., Hill, D., Auvinen, A., Barros-Dios, J. M., Baysson, H., Bochicchio, F., ... \& Heid, I. (2005). Radon in homes and risk of lung cancer: collaborative analysis of individual data from 13 European case-control studies. Bmj, 330(7485), 223.

46. Jordan, R. E., Cheng, K. K., Miller, M. R., \& Adab, P. (2011). Passive smoking and chronic obstructive pulmonary disease: cross-sectional analysis of data from the Health Survey for England. BMJ open, 1(2), e000153.

47. Chauhan, A. J., \& Johnston, S. L. (2003). Air pollution and infection in respiratory illness. British medical bulletin, 68(1), 95-112.

48. Taylor, A. F., Kuo, F. E., \& Sullivan, W. C. (2002). Views of nature and self-discipline: Evidence from inner city children. Journal of environmental psychology, 22(1), 49-63.

49. Fisk, W. J., \& Rosenfeld, A. H. (1997). Estimates of improved productivity and health from better indoor environments. Indoor air, 7(3), 158-172.

50. Ashrae, A. N. S. I. (2004). Standard 55-2004, Thermal environmental conditions for human occupancy. American Society of Heating, Refrigerating and Air-Conditioning Engineering, Atlanta, GA.

51. Jansz, J. (2011). Introduction to sick building syndrome. In Sick Building Syndrome (pp. 124). Springer Berlin Heidelberg.

52. WHO, (2002). The World Health Report 2002: Reducing Risks, Promoting Health Life. Geneva: World Health Organization.

53. Bonnefoy, X. (2007). Inadequate housing and health: an overview.International Journal of Environment and Pollution, 30(3-4), 411-429.

54. Lampietti, J., \& Meyer, A. (2002). When heat is a luxury: helping the urban poor of Europe and Central Asia cope with the cold. World Bank, Washington, DC.

55. Barreiro, J., Sánchez, M., \& Viladrich-Grau*, M. (2005). How much are people willing to pay for silence? A contingent valuation study. Applied economics, 37(11), 1233-1246.

56. Kohlhuber, M., Mielck, A., Weiland, S. K., \& Bolte, G. (2006). Social inequality in perceived environmental exposures in relation to housing conditions in Germany. Environmental research, 101(2), 246-255.
57. Bilger, M., \& Carrieri, V. (2013). Health in the cities: when the neighborhood matters more than income. Journal of Health Economics, 32(1), 111.

\footnotetext{
${ }^{a}$ Corresponding author: syahrulnizam@um.edu.my
} 